\title{
Surface Sterilization Protocol for Nodal Cultures of Potato (Solanum tuberosum L.)
}

\author{
Girma Gashu Kebede \\ Ethiopian Institute of Agriculture Research
}

\begin{abstract}
The process of surface sterilizing plant materials is a difficult step in constructing a plant tissue culture technique. Nodal explants from potted plants of Solanum tuberosum L. grown in the screenhouse were given various surface sterilization procedures before being introduced into sterile Murashige and Skoog (MS) culture. A total of 16 treatments were performed with varied periods of immersion in two sterilant successions: $70 \%(\mathrm{v} / \mathrm{v})$ ethanol $(20 \mathrm{~s}, 1 \mathrm{~min}, 3 \mathrm{~min}$, and $5 \mathrm{~min})$ and 10\% (w/v) calcium hypochlorite $(\mathrm{Ca}(\mathrm{ClO}) 2)$ granules $(5,10,15$, and $20 \mathrm{~min}$ ) at varying times, followed by three sterile distilled water rinses. After 4 weeks in culture, $70 \%$ ethanol $(20 \mathrm{~s})+10 \% \mathrm{Ca}(\mathrm{ClO}) 2(15 \mathrm{~min})$ and $70 \%$ ethanol $(3 \mathrm{~min})+10 \% \mathrm{Ca}(\mathrm{ClO}) 2(20 \mathrm{~min})$ treatments yielded $100 \%$ clean culture. $70 \%$ ethanol (20 seconds) Plus 10\% calcium (ClO) 2 (15 min) is recommended as the optimum surface sterilizing protocol since it produced $90 \%$ growth compared to $60 \%$ growth in $70 \%$ ethanol (3 $\mathrm{min})+10 \% \mathrm{Ca}(\mathrm{ClO}) 2(20 \mathrm{~min})$. This is a preliminary study, and more research is needed to develop an efficient, successful, and repeatable methodology for surface sterilization of various explants utilized for tissue culture of S. biafrae acquired from the open field.
\end{abstract}

Keywords: calcium hypochlorite $(\mathrm{Ca}(\mathrm{ClO}) 2$, Murashige \& Skoog, nodal explant, Solanum tuberosum L., surface sterilization.

DOI: $10.7176 / \mathrm{JNSR} / 12-13-01$

Publication date:July $31^{\text {st }} 2021$

\section{Introduction}

Plants can be cultured in vitro using vegetative shoots as a starting material/explant (Obembe, 2000). However, in vitro culture establishment is difficult due to the high microbial contamination loads they carry, particularly in the axillary nodes. Microbial contamination is typically avoided by using good surface sterilization of explants, as well as other aseptic procedures. Surface sterilization of explants is a technique that involves immersing explants in an adequate concentration of chemical sterilant(s) or disinfectant(s) for a set amount of time, resulting in a contamination-free culture. Various disinfectants are utilized, according to the literature, including ethanol (or isopropyl alcohol), sodium hypochlorite $(\mathrm{NaOCl})$, and calcium hypochlorite $(\mathrm{CaOCl})$. Hydrogen per oxide(H2O2), mercuric chloride (HgCl2), silver nitrate (AgNO3) and bromine water (Abrham, 2011; Singh et al., 2011). However, the disinfectant(s) required, as well as the type, concentration, and duration of exposure, differ by plant and plant part (Srivastava et al., 2010). Ethanol is a potent sterilizing agent that is also phytotoxic. It is typically used at a $70 \%(\mathrm{v} / \mathrm{v})$ concentration (Abbasi et al., 2016) for only a few seconds or minutes before being treated with another disinfectant (s). Hypochlorite, on the other hand, is a highly powerful bacteria killer that drastically decreases bacterial populations even at micromolar doses. However, sodium hypochlorite is a harsh disinfectant for explants, thus calcium hypochlorite, which is a moderate sterilant, is preferred (Abbasi et al., 2016; Badoni and Chauhan, 2009; Cruz-Martnez et al., 2017). Assareh and Sardabi (2005) found that Ca(ClO)2 was the most effective of three sterilizing agents $(\mathrm{Ca}(\mathrm{ClO}) 2, \mathrm{NaOCl}$, and $\mathrm{HgCl} 2)$ for sterilizing Ziziphus spinachristi (L.) Desf. The goal of this research is to create a surface sterilization strategy for the in vitro establishment of potato (Solanum tuberosum L.) nodal explants using commercially available ethanol and calcium hypochlorite.

\section{Materials and methodes}

Nodal explants of about $2-3 \mathrm{~cm}$ were taken from new growth flushes from potted plants of potato grown in the screenhouse. They were thoroughly cleaned with liquid detergent under running tap water and immersed in $70 \%$ ethanol for varying exposure times (20 seconds, 1 minute, 3 minutes, and 5 minutes), followed by surface sterilization with $10 \% \mathrm{Ca}(\mathrm{ClO}) 2$ for varying exposure times $(5,10,15$, and 20 minutes $)$ and then rinsed with three changes of sterile distilled water. The bleached ends of the sterilized single node explants were clipped and cultured on Murashige and Skoog (MS) basal (Murashige and Skoog, 1962) supplemented with $3 \%$ sucrose, $\mathrm{pH}$ 5.8, $0.8 \%$ agar, and autoclaved for 15 minutes at $121^{\circ} \mathrm{C}$. In the Laminar Flow Hood, the sterilizing and transfer procedures were completed. The cultures were incubated at $25^{\circ} \mathrm{C}$ in a growth environment with a 16-hour photoperiod and a light intensity of 3000 lux. Each treatment contained ten duplicates in the experiment, which was set up in a Completely Randomized Design. They were kept for four weeks, with measurements made on the percentage of clean cultures, germination frequency, and tissue survival. 


\section{Result and Discussion}

Surface sterilization of nodal explants has been done regularly with calcium hypochlorite, either alone or in conjunction with ethanol (70\%). The results of this investigation reveal that increasing the exposure duration to $70 \%$ ethanol was ineffective in eliminating pollutants from Solanum tuberosum $L$ nodal explants. This could be owing to the increased toxicity of the decontaminant as the concentration grew (Rodrigues et al., 2013). T3 had the best results (100\% clean culture) with a 20 -second exposure time, followed by T4 (79 \%).

T1 yielded the smallest percentage of clean cultures (54\%). The percentage clean culture grew as the exposure period increased from 5 to 15 minutes, but as the exposure time climbed to 20 minutes, the percentage clean culture decreased. This is consistent with Obembe (2000), who found that a step-wise treatment of $70 \%$ ethanol for 20 seconds followed by $10 \%(\mathrm{w} / \mathrm{v}) \mathrm{Ca}(\mathrm{ClO}) 2$ for 10 minutes was the best sterilization procedure for Cola nitida; and Slusarkiewicz-Jarzina et al. (2005), who found that surface sterilization of Cannabis sativa seeds in $\mathrm{Ca}(\mathrm{ClO}) 2$ solution for 15 minutes gave the best results. $\mathrm{T} 6$ produced the best results $(88$ percent clean culture) after a one-minute exposure duration, while other treatments produced the same percentage of clean cultures (54 percent) (Figure 1b). This contradicts dos Santos et al. (2015), who found that immersing leaf explants in $70 \%$ ethanol for 1 minute and then soaking in $10 \% \mathrm{Ca}(\mathrm{ClO}) 2$ for 30 minutes was the most effective, resulting in $90 \%$ disinfection. When the exposure period was increased to 3 minutes, the proportion of clean culture increased. T12 produced the greatest results (100\% clean culture), while T9 produced the least clean culture percentage $(20 \%)$. As the exposure period was prolonged for another 5 minutes, the proportion of clean culture decreased. T13 had the best outcome (100\% clean culture), T14 had the secondbest result (77\%), and T16 had the lowest percentage clean culture (40\%). It was also observed that pretreatment of Launaea taraxacifolia with $70 \%$ ethanol for 5 minutes, followed by step-wise double disinfection in $10 \%$ and $15 \%$ sodium hypochlorite, yielded good results (Obembe et al., 2017).

T3 (70 \% ethanol for 20 seconds followed by $10 \%$ calcium hypochlorite for 15 minutes) and T12 (70\% for 3 minutes followed by $10 \%$ calcium hypochlorite for 20 minutes) were the most effective disinfection treatments, with $100 \%$ of the explants remaining free of contamination after four weeks in culture. The survival rate of the sterilant was impeded as the exposure duration of the sterilant was increased. T3 ( $70 \%$ ethanol for 20 seconds $+10 \%$ calcium hypochlorite for 15 minutes) had a survival and growth rate of $90 \%$, compared to $60 \%$ in T12 (70\% ethanol for 3 minutes $+10 \%$ calcium hypochlorite for 15 minutes).

\section{Conclusion}

Immersion of S. biafrae nodal explants taken from the screen house in $70 \%$ ethanol $(20 \mathrm{~s})+10 \% \mathrm{Ca}(\mathrm{ClO}) 2(15$ $\mathrm{min})$ and $70 \%$ ethanol $(3 \mathrm{~min})+10 \% \mathrm{Ca}(\mathrm{ClO}) 2(15 \mathrm{~min})$ can achieve $90 \%$ disinfection $(20 \mathrm{~min})$. Meanwhile, $70 \%$ ethanol $(20 \mathrm{~s})+10 \% \mathrm{Ca}(\mathrm{ClO}) 2(15 \mathrm{~min})$ will be used for survival and growth.

\section{Reference}

Abbasi, Z., Singh, R. P., Gautam, D. N. S. (2016) A novel aseptic technique for micropropagation of Aloe vera mill. Advanced Herbal Medicine 2: 47-60.

Abrham, G. G., (2011) In vitro propagation of Boswellia papyrifera (Del.) Hochst. Haramaya University.

Assareh, M. H., and Sardabi, H. (2005). Macropropagation and micropropagation of Ziziphus spina-christi. Pesquisa Agropecuária Brasileira, 40, 459-465.

Badoni, A., Chauhan, J. S. (2009) In vitro sterilization protocol for micropropagation of Solanum tuberosum cv. 'Kufri Himalini'. Academia Arena 1: 5-8.

Cruz-Martínez, V., Castellanos-Hernández, O. A., Acevedo-Hernández, G. J., TorresMorán, M. I., GutiérrezLomelí, M., Ruvalcaba-Ruiz, D., Zurita, F., RodríguezSahagún, A. (2017) Genetic fidelity assessment in plants of Sechium edule regenerated via organogenesis. South African Journal of Botany 112: 118-122.

Dos Santos, M. R. A., Ferreira, M. D. G. R., Braga, A. G. S. (2015) Callogenesis in leaf explants of Annona glabra L. Australian Journal of Basic and Applied Sciences 9: 235-238.

Murashige, T., Skoog, F. (1962) A revised medium for rapid growth and bio assays with tobacco tissue cultures. Physiologia Plantarum 15: 473-497.

Obembe, O. O. (2000) Studies on Kola tissue culture I: Protocols for establishing Kola tissues in vitro. Nigerian Journal of Science 34: 271-276.

Obembe, O., Bello, O., Aworunse, O., Popoola, J., Akposibruke, O., Olukanmi, B., Olayode, M. (2017) In vitro Multiple Shoots Formation in Wild Lettuce (Launaea taraxacifolia) (Willd.) Amin ex C. Jeffrey. Annual Research and Review in Biology 19: 1-8.

Rodrigues, D. T., Novais, R. F., Venegas, V. H. A., Dias, J. M. M., Otoni, W. C., Villani, E. M. D. A. (2013) Chemical sterilization in in vitro propagation of Arundina bambusifolia Lindl. and Epidendrum ibaguense Kunth. Revista Ceres, Viçosa 60: 447-451.

Singh, V., Tyagi, A., Chauhan, P. K., Kumari, P., Kaushal, S. (2011) Identification and prevention of bacterial contimination on explant used in plant tissue culture labs. International Journal of Pharmacy and 
Pharmaceutical Sciences 3: 160- 163.

Slusarkiewicz-Jarzina, A., Ponitka, A., Kaczmarek, Z. (2005) Influence of cultivar, explant source and plant growth regulator on callus induction. Acta Biological Cracovians Series Botanica 47: 145-151.

Srivastava, N., Kamal, B., Sharma, V., Negi, Y. K., Dobriyal, A. K., Gupta, S., Jadon, V. S. (2010) Standardization of sterilization protocol for micropropagation of Aconitum heterophyllum-An endangered Medicinal Herb. Academia Arena 2: 37- 42. 